\title{
Diplomatspillet om Nordpolen
}

Af Ole Lorenzen

Isen er stærkt på retur i det arktiske område om sommeren. Det åbner nye muligheder for sejlads, turisme, fiskeri og efterforskning efter olie eller andre værdifulde råstoffer. Og dermed også for et omfattende diplomatisk spil om rettigheder til sejlruter, undergrunden og beskyttelsen af det meget følsomme miljø.

Allerede i 1922 kunne fangerne i det arktiske område berette om, at der var begyndt at være mindre is i området om sommeren end tidligere. Siden er det gået stærkt. Kurven for isens forsvinden er nærmest identisk med kurven for det stigende forbrug af fossile brændstoffer og dermed udledningen af $\mathrm{CO}_{2} \mathrm{i}$ atmosfæren.

Den 25. februar i år nåede udbredelsen af isen i Arktis formentlig det laveste toppunkt, der er målt siden de årlige målinger begyndte i 1978. Normalt ville isen fortsætte med at tiltage frem til midten af marts, men det er der ifølge DMI intet, der tyder på i skrivende stund. Om det betyder, at sommeren vil byde på det laveste lavpunkt er ikke til at sige. Det afhænger af, hvordan sommeren bliver.

Men det er ikke noget urealistisk scenario, at Arktis om en årrække vil være fuldstændigt isfrit i kortere perioder om sommeren.
Mere hav giver flere muligheder

Når isen forsvinder, åbner det naturligvis en række muligheder, der ikke hidtil har været der. Hvis der er fisk, kan der fiskes. Fragtskibe får nye muligheder for at fragte Asiens varer til Europa. Der kan søges efter værdifulde råstoffer i undergrunden. Og velhavende turister kan opleve at have været på Nordpolen.

Dermed opstår spørgsmålene: Hvordan skal fiskeriet reguleres, så bestandene ikke tager skade? Hvem kontrollerer fragtruterne? Hvem ejer undergrunden? Og hvad nu, hvis et krydstogtskib med 5.000 mennesker ombord forulykker, eller en supertanker fyldt med råolie slår læk?

Disse spørgsmål, og hvordan landene omkring Arktis og i resten af verden forholder sig til dem, har flere danske forskningsinstitutioner på det seneste beskæftiget sig med og udgivet rapporter om.

Samtidig intensiveres det diplomatiske spil mellem landene i det arktiske område, og overvejelserne rummer også spørgsmålet: Udløser spillet om Arktis en international krise eller ligefrem en spændt situation?

I tre rapporter fra henholdsvis Center For Militære Studier ved Københavns Universitet, DIIS og Forsvarsakademiet

Ole Lorenzen er journalist og deltog i februar i år i SDل’s efteruddannelseskursus for journalister 'Arktis - klodens nye hotspot'. 
(Kina, Grønland, Danmark - konsekvenser og muligheder i Kinas Arktispolitik. Center for Militære Studier, Københavns Universitet, 2014; Arktiske Usikkerheder. DIIS, 2014; Ruslands strategi i Arktis. Forsvarsakademiet, 2014.) er konklusionen samstemmende, at der ikke er nogen grund til at tro, at Arktis i sig selv vil udløse en spændt situation eller ligefrem en militær konflikt.

Denne vurdering deles af professor i statskundskab ved Norges Arktiske Universitet Rasmus Bertelsen, der følger udviklingen fra sin stol i Tromsø:

"Der er ringe grund til at tro, at der vil udvikle sig en egentlig militær konflikt om Arktis. Langt de fleste formodede ressourcer befinder sig i områder, hvor der ikke er tvivl om rådighedsretten", siger Rasmus Bertelsen.

\section{Artisk Råd}

Arktisk Råd er det internationale forum, hvor alle emner på nær de militære og de territoriale ejerforhold vedrørende den arktiske udvikling drøftes.

Finland tog i 1989 initiativ til at samle de otte arktiske lande til et møde, der primært handlede om de voksende miljøproblemer i Arktis. Processen udviklede sig til, at Arktisk Råd blev oprettet i 1996. De otte lande er Kongeriget Danmark, Norge, USA, Canada, Rusland, Sverige, Finland og Island. Desuden er der seks permanente medlemmer af rådet, der repræsenterer de seks oprindelige folkefærd, der lever i Arktis.

Dertil kommer, at en række lande har fået observatørstatus, hvilket giver ret til at deltage i rådets møder og deltage i debatten. Den fremmeste observatør er Kina, hvis strategi for Arktis vil blive beskrevet senere. EU har søgt om lov til at blive permanent observatør, men er ikke lukket ind i varmen endnu.
Arktisk Råd er en mellemstatslig organisation, og der kan således kun træffes beslutninger i enighed, og der er ingen sanktionsmuligheder ved brud på indgåede aftaler. Først for ganske nylig fik rådet i øvigt sit eget faste sekretariat med base i Tromsø i Norge.

Formandskaberne er to-årige og går på skift mellem de otte lande. Canada afsluttede sit andet formandskab den 24-25. april i år med et ministermøde. Mødet bekræftede Kirunadeklarationen, og USA overtog formandskabet. USA's fokus de næste to år vil være at forbedre levevilkårene for de oprindelige befolkninger, sikre freden og stabiliteten i Arktis og fortsætte indsatsen mod klimaforandringerne.

Ruslands udenrigsminister Sergej Lavrov kom ikke, hvilket førte til spekulationer om en forbindelse til konflikten i Ukraine. Svaret er snarere, at miljøministeren, der kom i stedet, passede bedre til mødets dagsorden. Og dermed er det en bekræftelse på, at andre konflikter ikke synes at forstyrre det arktiske samarbejde.

\section{Kirunadeklarationen}

Den første runde formandskaber sluttede den 15. maj 2013 i Kiruna i Sverige med vedtagelsen af Kirunadeklarationen.

Den fastslår den gode udvikling i samarbejdet og anerkender, at der er en lang række hensyn at tage til det arktiske område for så vidt angår de mennesker, der bor der, miljøet og udnyttelsen af ressourcerne. Og den fastslår, at der er grund til at agere mod den globale opvarmning som følge af udledningen af drivhusgasser.

Endelig understreger den alle medlemsstaters interesse $i$, at udviklingen og samarbejdet om Arktis skal udvikle sig fredeligt og konstruktivt. Havde der stået det 
modsatte, havde det nok også vakt mere opsigt.

I Kiruna blev der desuden nedsat en række arbejdsgrupper, der skulle fremlægge rapporter med anbefalinger til det videre arbejde på ministermødet den 24.25. april. Det var også i Kiruna, at det blev besluttet at oprette det faste sekretariat i Tromsø. Endelig blev Kina, Indien, Japan, Singapore og Sydkorea budt velkomne som faste observatører i Arktisk Råd.

\section{Kinas strategi for Arktis}

Kina har i lang tid været interesseret i Arktis. Både ud fra en strategi om at virke som en stormagt i det internationale spil, men også ud fra et ønske om at være med i kampen om råstofferne i Arktis, både dem på land og de mulige under havbunden.

Kinas Arktispolitik er udførligt beskrevet i Kina, Grønland, Danmark - konsekvenser og muligheder i Kinas Arktispolitik. Kinas interesse for minedrift i Grønland er velkendt. Mindre kendt er det vel, at den største udenlandske ambassade i Reykjavik er Kinas. Kina og Island har indgået frihandelsaftaler, der utvivlsomt er en del af begrundelsen for Islands manglende interesse for medlemskab af EU.

Og med den smeltende is øjner Kina pludseligt muligheden for at forkorte sejlruten fra Kina og til de attraktive markeder omkring Atlanterhavet. Der spares både tid og store mængder brændstof ved at sejle nord om Rusland og gennem Nordøstpassagen til Europa, og muligheden for at sejle med større skibe, der kke skal gennem Malaca-strædet og Suezkanalen, er der også.

Kina købte tidligt en isbryder af Ukraine og byggede den om til Xuelong, der kan bryde is i 1,2 meters tykkelse. Xuelong gennemsejlede Nordøstpassagen og lagde til kaj i Reykjavik i 2012. Kina har også en forskningsstation på Svalbard. Kina har underskrevet Svalbardtraktaten og har som sådan adgang til forskning og andre aktiviteter på Svalbard.

I rapporten fra Center For Militære Studier er konklusionen, at Kinas interesser i Arktis alene er økonomiske. Disse interesser tilgodeses ikke ved en aggressiv fremfærd eller forsøg på at militarisere Arktis. I stedet er det vigtigt for Kina at fremstå troværdig på den internationale scene og argumentere for synspunktet om, at udviklingen i Arktis er af interesse ikke bare for landene omkring, men for hele det internationale samfund.

\section{Arctic 5}

Arctic 5 er nok bedst kendt i Danmark, fordi daværende udenrigsminister Lene Espersen den 29. marts 2010 holdt ferie i stedet for at deltage i et møde i Arctic 5, men i stedet sendte justitsminister Lars Barfoed. USA's daværende udenrigsminister Hillary Clinton deltog og betegnede senere mødet som vigtigt.

Afbuddet blev anledningen til en langvarig storm mod Lene Espersen, som til sidst førte til hendes afgang som konservativ partiformand i januar 2011. Om hendes tilstedeværelse på mødet i Arctic 5 havde gjort nogen nævneværdig forskel er nok tvivlsomt. Men signalet om ikke at ville mødes med Hillary Clinton var det afgørende.

Artic 5 er de fem lande, der har grænser til havet omkring Nordpolen: Kongeriget Danmark, Norge, Rusland, USA og Canada. Det er de fem lande, der har territorialkrav i Arktis og blandt andet skal finde ud af, hvem der ejer Nordpolen.

Det ironiske ved Lene Espersens udeblivelse er, at det faktisk var hendes forgænger som udenrigsminister, Per Stig Møller, der tog initiativet til at skabe Arctic 5 under Arktisk Råd. Det siges da også, at 
Arctic 5 er nok bedst kendt i Danmark, fordi daværende udenrigsminister Lene Espersen den 29. marts 2010 holdt ferie i stedet for at deltage i et møde i Arctic 5, men i stedet sendte justitsminister Lars Barfoed. USA's daværende udenrigsminister Hillary Clinton deltog og betegnede senere mødet som vigtigt.

Per Stig Møller protesterede voldsomt internt i regeringen, da han blev klar over Lene Espersens afbud.

Den 2. august 2007 anbragte en privat - officielt - ekspedition ved hjælp af en avanceret miniubåd et russisk flag af titanium på bunden af havet under Nordpolen. Som da USA satte det amerikanske flag på månen, hævdede Rusland ikke på den baggrund, at Nordpolen er russisk. Fra meget gammel tid er det ellers det at sætte et flag først, der markerer retten til et område.

I Martin Breums bog Når Isen Forsvinder (Gyldendal, 1. udgave 2011, revideret udgave 2013) er processen nøje beskrevet. Der er voldsomme spændinger mellem Rusland og den øvrige verden oven på EU's udvidelse mod Øst og Ruslands fremfærd i Georgien og over for Estland, Letland og Litauen.

Per Stig Møller undfanger ideen om, at de fem lande med grænse til Det Arktiske Ocean skal samles og underskrive en erklæring om at dele oceanet fredeligt og i henhold til de internationale traktater herom. "Jeg konstaterer, at Danmark kan tage et initiativ og gøre noget ved det. USA kunne ikke gøre det, for russerne vil aldrig skrive under på noget $\mathrm{i}$ USA. Rusland ville af samme grund aldrig kunne tage initiativet. Norge og Danmark kunne, og så gjorde jeg det", siger Per Stig Møller i bogen.

\section{Ilulissat-erklæringen}

Det skulle vise sig ikke at blive nogen nem proces, men faktisk lykkes det efter heftige diplomatiske bestræbelser at samle de fem lande i den grønlandske by Ilulissat. Og den 28. maj 2008 kan Per Stig Møller sidst på eftermiddagen fortælle den forsamlede verdenspresse, at de fem lande er nået til enighed.

Med Udenrigsministeriets egne ord: "Mødet resulterede i vedtagelsen af en politisk erklæring, Ilulissat-erklæringen, som sender et stærkt politisk signal til både de lokale befolkninger og til resten af verden om, at de fem kyststater vil handle ansvarligt, når det gælder den fremtidige udvikling i Polarhavet. Landene har politisk forpligtet sig til at løse uoverensstemmelser gennem forhandlinger, og har dermed forhåbentligt én gang for alle aflivet myterne om et kapløb mod Nordpolen."

De fem lande har gentagne gange siden bekræftet, at de agter at stå ved erklæringen.

\section{Hvem ejer Nordpolen?}

Med Ilulissat-erklæringen står det klart, at FN's havretskommission bliver det forum, hvor ejerforholdene til Det Arktiske Ocean og Nordpolen skal afgøres. Processen med at anmelde krav har allerede været i gang i en årrække, men blev for alvor interessant for de danske medier i efteråret 2014, hvor Danmark officielt afleverede sit krav. Et krav der er ganske omfattende, og som går helt fra Grønland tværs over Nordpolen til den russiske territorialgrænse.

Kravet blev opfattet som værende meget aggressivt over for Rusland, og udenrigsministeriets embedsmænd har siden forsikret igen og igen, at det er et forhandlingsoplæg.

Rusland og Norge har lavet en aftale om grænsedragningen, og Norge har ikke 
meldt krav ind, der berører det område, inklusive Nordpolen, som Danmark har rejst krav på. USA's krav ud for Alaska er beskedne med begrænsede overlapninger til det russiske, og USA gør ikke krav på Nordpolen. I det hele taget er USA's interesse i Arktis beskeden, og Arktis er ikke noget, der ifølge pålidelige kilder optager Pentagon (USA's forsvarsministerium) stort.

Det efterlader Canada, Rusland og Kongeriget Danmark tilbage.

Afgørende for ejerskabet af Nordpolen er Lomonosovryggen, der strækker sig på havbunden tværs over oceanet. Tilhører den Kongeriget, som det hævder, er Nordpolen en del af det. Tilhører den Rusland, som Rusland hævder, er den russisk. Det kommer de næste mange, mange års juridiske og diplomatiske diskussioner til at handle om.

\section{Hvad vil Putin?}

I januar i år udgav Forsvarsakademiet ved Ph.d., adjunkt Jørgen Staun en rapport Ruslands strategi for Arktis. Jørgen Staun argumenterer overbevisende for, at Ruslands udenrigspolitik i vid udstrækning er et anliggende for præsidenten, og altså p.t. Vladimir Putin, således som det før præsidenterne var generalsekretærerne for kommunistpartiet og før dem igen zarerne. Og som nævnt i indledningen er hovedkonklusionen, at der ikke er grund til at tro, at Rusland vil bruge Arktis til at skabe en egentlig diplomatisk eller militær konflikt. Arktis bruges som led i Putins bestræbelser på at genskabe Rusland som en international stormagt, men først og fremmest er Ruslands interesse i Arktis af økonomisk karakter.

Ganske mange af verdens tilbageværende olie og naturgasreserver skønnes at befinde sig i Barentshavet ved Ruslands nordkyst. Med den lave oliepris i øjeblikket er fore- komsterne imidlertid ikke økonomisk interessante. Dertil kommer, at Rusland ikke selv har teknologien til at bore efter ressourcer på meget dybt vand under arktiske forhold. Hertil skal Rusland bruge teknologi fra udlandet, og derfor rammer de internationale sanktioner på grund af situationen i Ukraine hårdt. De forhindrer nemlig de store internationale olie- og gasselskaber $\mathrm{i}$ at samarbejde med de russiske. Derfor har Rusland vendt sig lidt mod Kina, men er samtidig nervøs for, at Kina får en for stor økonomisk indflydelse.

Herredømmet over Nordøstpassagen spiller derudover også en rolle i den russiske strategi.

Men Rusland har altså valgt en lidt mere tilbageholdende stil end Kongeriget, når det gælder de territoriale krav. Ruslands krav går således ikke helt til territorialgrænsen ved Grønland, således som Kongerigets går helt til Ruslands grænse. Rusland har indtil nu valgt at stille, hvad man kunne kalde realistiske krav, hvor Kongerigets er det maksimale.

Ruslands endelige krav til kontinentalsokkelen ventes senere i år eller i 2016. Dér vil det vise sig, om Rusland så vil bruge samme taktik som Danmark.

\section{Kongeriget Danmark i Arktis}

Igennem hele denne artikel er Danmark konsekvent omtalt som Kongeriget Danmark eller blot Kongeriget. Det skyldes den enkle kendsgerning, at hvis ikke Danmark og Grønland indgik i et rigsfællesskab, havde Danmark ingen interesser i Arktis. Noget grønlandske politikere og diplomater nok skal gøre opmærksom på, hvis Udenrigsministeriets embedsmænd eller danske politikere kommer til at tale om "de danske interesser i Arktis". Intet tyder på, at der i de dele af Det Arktiske Ocean, der måtte blive tildelt Kongeriget, findes nævneværdige ressourcer, der kan 
udnyttes. Hvorfor så den store interesse?

Det har daværende udenrigsminister Martin Lidegaard gjort meget klart i Martin Breums bog Balladen om Grønland (Gyldendal, 2014):

"Den indflydelse, vi har på de internationale regler og den politik, der skal føres i Arktis i fremtiden, er rigtig meget værd i geopolitisk forstand. Det betyder, at vi bedre kan forfølge Danmarks overordnede udenrigspolitiske interesser og mål. Vi kan arbejde for trygge rammer for Danmark, arbejde på at den danske befolkning kan leve i sikkerhed; vi kan sikre multilaterale rammer, der skaber så store muligheder for små landes indflydelse som muligt, fredelig konfliktløsning, godt miljø og en socialt afbalanceret udvikling. Alle disse helt vitale interesser får vi en mulighed for at varetage aktivt, fordi vi er forbundet med Grønland. Uden Grønland kunne vi ikke tillade os nær samme styrke i stemmeføringen, og det gælder også ud over den arktiske region - bare i lidt mere overført betydning."

Så Danmark har i kraft af Grønland en stor international stemme.

Hvad så med Danmark og Arktis på det meget lange sigt? Rasmus Bertelsen har også indgående studeret udviklingen i Rigsfællesskabet, helt fra da Island var en del af det. Han er overbevist om, at Grønland før eller siden vil forlade Rigsfællesskabet på samme måde som Island.

"Og det vil jo så gøre Danmark til det første postarktiske land” siger Rasmus Bertelsen eftertænksomt. 